\title{
Holocene evolution of a barrier island system, Ria Formosa, South Portugal
}

\author{
Carlos Sousa, (i) Tomasz Boski and Laura Pereira
}

\begin{abstract}
Holocene evolution of the Ria Formosa barrier island system was studied through the examination of a large subsurface dataset acquired from I9I boreholes and five seismic refraction profiles. Two boreholes with total depths of 26 and $16.5 \mathrm{~m}$ were selected for a multi-proxy detailed laboratory analysis, including mean grain size distribution, organic matter (OM) content, color variation, shell identification, and benthic foraminifera assemblages. Selected cores are thought to be representative of the identified depositional sub-basins. Subsurface age data from 16 AMS ${ }^{14} \mathrm{C}$ dated samples were plotted against depth and resulted in a coherent age model of sedimentary infill. The system evolution was largely controlled by sediment availability, accommodation space, and Holocene sea level rise, first at a rapid rate of $7 \mathrm{~mm} / \mathrm{yr}$ from $10 \mathrm{kcal}$ yr BP to $7.25 \mathrm{kcal}$ yr BP, followed by a slowdown to I.I $\mathrm{mm} / \mathrm{yr}$ until present. A conceptual model for the origin and Holocene evolution of the Ria Formosa barrier island system implies three main steps, leading to the present system geomorphology: (I) marine flooding of incised palaeovalleys by the rapid transgression of palaeovalleys in the early Holocene; (2) development of a proto-barrier island chain perched on Pleistocene detritic headlands and steeper interfluve areas during the early to middle Holocene; and (3) full development of the barrier islands chain and enclosing of the coastal lagoon, followed by the maturation of the system with subsequent siltation and salt marsh expansion from the middle Holocene until present. The onset of barrier system formation dates back to ca. $8 \mathrm{kcal}$ yr BP, predating previously proposed age.
\end{abstract}

\section{Keywords}

barrier island system, Holocene, palaeoenvironmental reconstruction, palaeosurface model, Ria Formosa, sea level rise

Received 23 April 2018; revised manuscript accepted 27 August 2018

\section{Introduction}

Barrier islands systems, succinctly described as long and relatively narrow sandy islands parallel to the shore and separated from it by a backbarrier lagoon, represent almost $10 \%$ of all continental shorelines. The vast majority occur in wave dominated to mixed-energy regimes $(88 \%)$ and on wide, low-relief coastal plains with shallow embayed estuaries (63\%) (Stutz and Pilkey, 2011).

The origin and evolution of these systems is largely determined by an interaction of several processes, namely, sediment availability, hydraulic transport mechanisms (wave energy versus tidal range), accommodation space controlled by antecedent geomorphology, and most importantly, sea level (SL) changes (Carter and Woodroffe, 1994; Van Heteren, 2015). Despite marked differences on continental, regional and local scales, depending on a variety of factors, two periods of Sea Level Rise (SLR) during the last ca. 15,000 years are observed (Costas et al., 2016; Fairbanks, 1989; Pirazzoli and Pluet, 1991; Stanley, 1995). The first lasted until approximately the middle Holocene (7500-6000 years ago) with fast rates ranging from $7 \mathrm{~mm} / \mathrm{yr}$ to $20 \mathrm{~mm} / \mathrm{yr}$, when it slowed down substantially to ca $1 \mathrm{~mm} / \mathrm{yr}$. This deceleration corresponds to the maximum flooding of previously exposed continental shelves (Lambeck et al., 2002) and marks a generalized reshaping of coastal morphology worldwide, whose contours roughly approached the presently observed (Smith et al., 2011).

The most widely cited conceptual models that explain the origin of barrier islands systems are according to Davis (1994) and Woodroffe (2003): (1) breaching of headland attached barrier spits, accreted from longshore transport (Fisher, 1968); (2) landward migration of barriers formed at SL lowstands by means of upward shoaling and accumulation of sand through wave action (Swift, 1975); and (3) drowning of beach ridges during rapid SLR phase (Hoyt, 1967). A fourth model that comprises the dynamics of the two first previously cited models was recently highlighted by Hayes and Fitzgerald (2013). In this model, four main stages succeed and are closely dependent on the rate of SLR and pre-inundation topography: (1) with a fast SLR (late Pleistocene/early Holocene), fast migrating sediment deposits move across the mid-continental shelf, leaving a thin lag deposit over the ravinement surface; (2) pre-Holocene river valleys are inundated, giving place to the development of estuaries over an irregular topography; (3) following the mid-Holocene stillstand, longshore sediment transport and tidal range become the dominant factors in barrier system development, with spit formation at barrier ends/estuary entrances and tidal inlets stabilization; and (4) development of a mature system, where tidal inlet position (migration/fixation) and sand dune systems formation above storm surge levels (related to washover frequency) retard barrier

Centro de Investigação Marinha e Ambiental (CIMA), Universidade do Algarve, Portugal

\section{Corresponding author:}

Carlos Sousa, Centro de Investigação Marinha e Ambiental (CIMA), Universidade do Algarve, Campus de Gambelas, Faro 8005-139, Portugal.

Email: cssousa@ualg.pt 
translation (Carter and Woodroffe, 1994), in either direction, landward (transgressive) or seaward (prograding or regressive). Regardless of the accepted model of barrier island system formation, there is a clear relation between the development of barrier island systems and SLR stillstands, where falling SLR rates promote sediment accumulation leading to barrier widening and seaward shoreline movement (Oliver et al., 2017).

Sediment transport, either transversal or lateral with respect to the coastline direction, is largely controlled by hydrodynamic processes where SLR rate plays a decisive role. Fast rates induce migration of transgressive sedimentary bodies through barrier rollover mechanisms (retrograding washover deposits) or even lead to in-place drowning (Lorenzo-Trueba and Ashton, 2014; McBride et al., 1995). With lower SLR rates, the sedimentary bodies experience other behaviors, namely, spit elongation parallel to the coast, dynamic equilibrium, or progradation (McBride et al., 1995). The process leading to the formation of these siliciclastic bodies depends on available sediment sources, initially dispersed in the proximal continental shelf and transferred toward the shoreline by wave action during the transgressive phase, in what was termed a cannibalistic process (Walker and James, 1992). Sediment trapping/deposition is strongly influenced by the topography antecedent to transgression (Belknap and Kraft, 1985; Riggs et al., 1995). Therefore, coastal lithosomes on a topographically varied surface will have portions of their stratigraphic column preserved in valleys, but the remainder may be destroyed, either as the shoreface erosive zone migrates over them during transgression or as result of tidal inlet migration (Denny et al., 2013; Gao and Collins, 2014). Despite the general agreement about the main controlling factors, most extensive barrier island chains have a complex response to SLR, where substrate composition, substrate slope, SLR rate, and sediment supply rate are considered to be the most important factors (Moore et al., 2010).

In the Atlantic Iberian coastal systems, widespread deposition begun as a result of the postglacial marine transgression, inundating and quickly infilling incised Pleistocene river valleys such as the Guadiana (Boski et al., 2008), Guadalquivir (Dabrio et al., 2000), and Tejo (Vis et al., 2008) at an average rate of ca. $7 \mathrm{~mm} /$ yr. During this phase, embracing the late Pleistocene and early Holocene, vertical accretion dominated the depositional process in coastal traps (Delgado et al., 2012; Trog et al., 2013). According to Dabrio et al. (2000) and Moura et al. (2007), in the following period from middle Holocene, that is, 6500 years ago until present, SLR slowed down to ca. $1 \mathrm{~mm} / \mathrm{yr}$, reducing at the same time the sedimentation (Delgado et al., 2012; Lario et al., 2002). Subsequent evolution of the coastal geomorphology assumed a more regional, laterally complex pattern with emergence of new coastal features such as sand barriers, spits, and coastal lagoons (Dias et al., 2000).

The small number of available studies focused on the formation and Holocene evolution of Ria Formosa barrier islands system points to barrier island migration toward the continent during the rapid transgression phase, later reshaped by extreme events and reworked by prevailing hydrodynamic processes (Andrade et al., 2004; Bettencourt, 1994; Pilkey et al., 1989). Although it is implied that the general architecture of the barrier chain may reflect the inherited shelf morphology, none of the previous models completely explains the present-day geomorphological shape of Ria Formosa. The existing complex system of ephemeral creeks and rivulets draining the emerged coastal plain, adjacent to Ria Formosa also suggests an important role that the antecedent topography may have played in shaping present coastline of Central Algarve. Therefore, in order to better time constrain the conceptual models and set the basis for future numeric simulations of the lagoon/barrier system evolution, we carried out this study which aims to reconstruct the pre-transgression surface and the chronological sequence of sedimentary processes occurred on that surface.
More specifically, the aims of this work will correspond to (1) apply a pre-Holocene digital terrain model (DTM) (Sousa et al., 2014) as a baseline surface for the system evolution, (2) establish an age model for the studied sedimentary sequences, (3) reconstruct the sedimentary architecture and palaeoenvironments of the Ria Formosa sedimentary infill, and (4) outline a conceptual model for evolutionary steps of barrier island system development.

\section{Regional setting}

The Ria Formosa is a system composed of a costal lagoon enclosed behind a sequence of five barrier islands and two spits, extending nearly $55 \mathrm{~km}$ along the Southern coast of Portugal $\left(37^{\circ} \mathrm{N} ; 7^{\circ} 56^{\prime} \mathrm{W}\right)$. Two of its sixtidal inlets were artificially opened and stabilized during the 20th century. Main wave directions fall in two quadrants, W-SW direction (71\%) and SE-NW (23\%) (Costa et al., 2001), thus creating two differentiated areas in terms of exposure to wave energy due to its triangular shape (elongates approximately $6 \mathrm{~km}$ in its distal section). Mean annual significant wave height is $1 \mathrm{~m}$, with short lived winter SW storms with waves of up to $6 \mathrm{~m}$ height (Filipe et al., 2000). Tidal regime is almost macrotidal (maximum tidal range of $3.5 \mathrm{~m}$ ), semidiurnal, with an average range of 2.8 and $1.3 \mathrm{~m}$ for spring and neap tides, respectively (Pacheco et al., 2008). Resulting barrier morphology is markedly wave-dominated (Davis, 1994), misrepresentative of the relationship between mean annual wave height and tidal range proposed by Davis and Hayes (1984), and as such reclassified as mixed-energy, wave dominated (Stutz and Pilkey, 2011). Modern barrier development presents four main stages, resulting from varying dominant physical processes as foredune erosion, overwash, Aeolian transport, and lagoon tidal currents (Ferreira et al., 2016). Intertidal features of the Ria Formosa system occupy almost $90 \%$ of its total area, of which only $14 \%$ are permanently flooded (Andrade et al., 2004). Extensive salt marshes (SMs), sand, and muddy flats and a complex tidal channel network are the main geomorphological features. Land reclamation since the beginning of the 20th century modified significantly the maximum continental tidal reach (Arnaud-Fassetta et al., 2006). The continental bordering unit of the lagoon corresponds to (1) PlioPleistocene Ludo Formation (Moura and Boski, 1999), composed mainly of red clayey sands with rounded pebbles of quartz and iron nodules and (2) Jurassic to Miocene limestone, silts, marls, and beach rock (Chester, 2012), both cut through several valleys. There is no significant permanent fluvial discharge into the Ria Formosa lagoon. The inflow of fresh water occurs ephemerally during the winter rainy season through a system of small rivulets draining small watersheds. Main tributaries and their watershed areas are as follows (from west to east): Ludo/São Lourenço (60 $\left.\mathrm{km}^{2}\right)$, Biogal/ Marchil $\left(52 \mathrm{~km}^{2}\right)$, and Rio Seco $\left(70 \mathrm{~km}^{2}\right)$. Due to the absence of major fluvial discharge, the sediments which are accreted to the system are assumed to originate either from the erosion of sandy cliffs and subsequent longshore transport or from the inner shelf (Davis, 1994). Long periods of high-intensity storms and associated post-storm recovery account for the majority of cross-shore sediment transport, while shorter period and low-intensity storms are related to longshore transport dominance (López-Dóriga and Ferreira, 2017).

\section{Methods}

\section{Field data: Boreholes, seismic profiles, and surface data acquisition}

In order to reconstruct the origin and evolution of the Ria Formosa Barrier Island System (RFBIS), a combination of three subsurface data acquisition techniques were performed in several campaigns: (1) 41 manual cores by means of Eijkelkamp 3 


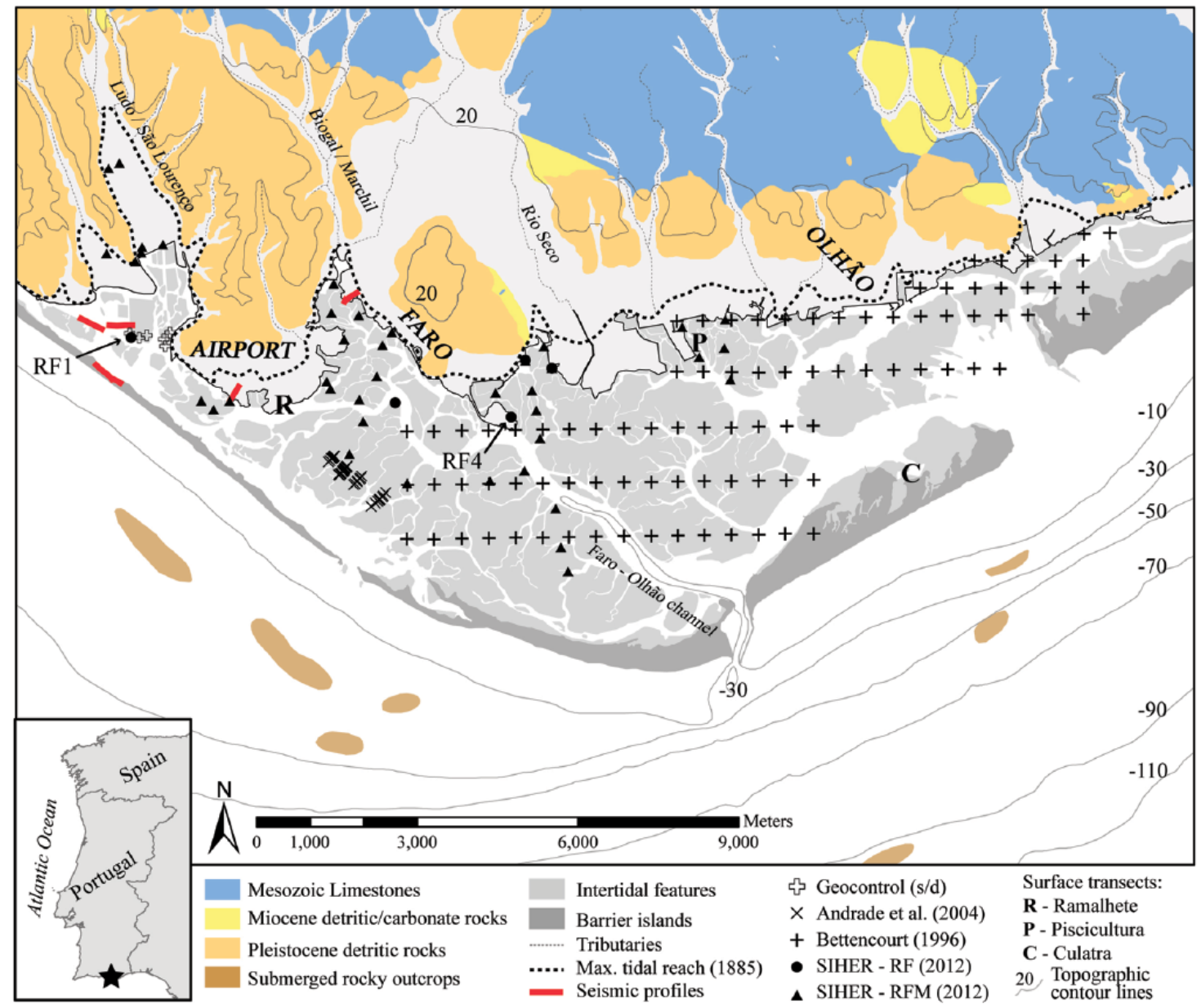

Figure I. Map of the study area, highlighting the location of boreholes, seismic profiles, submerged rocky outcrops, and surface sample sites.

$\mathrm{cm}$ diameter hand auger, totaling $151 \mathrm{~m}$; (2) five mechanical cores by means of $6 t$ roto-percussion drilling rig equipped with a $10 \mathrm{~cm}$ diameter core barrel, totaling $74 \mathrm{~m}$; and (3) Seismic refraction surveys along five transects with a total length of $2016 \mathrm{~m}$. Site selection mainly followed the axes of terminal stretches of existing tributary valleys (Figure 1), complementing previously acquired data from other borehole campaign sources (Andrade et al., 2004; Bettencourt, 1994; Faro Airport geotechnical surveys, n.d.). Manual cores were photographed and described in situ in terms of texture and lithological units, color, sedimentary features, discernible organic material, and presence of carbonate macrofossils. Reaction to hydrochloric acid $(\mathrm{HCl})$ was also annotated in order to assess disseminated/ microfossil carbonate content. Core lengths ranged between a maximum of $8.6 \mathrm{~m}$ and minimum of $1.55 \mathrm{~m}$, depending on the presence of sandy horizons $(>50 \mathrm{~cm})$ or the pre-Holocene, Plio-Pleistocene clayey red sands substrate. Samples were collected for laboratory analysis according to changes in lithology, on average every $0.8 \mathrm{~m}$. After extraction from the core barrel, mechanical cores, whose recovery varied between $80 \%$ and $100 \%$, were transferred to plastified cardboard boxes and transported to the laboratory where they were split longitudinally in two halves for description, photography, sampling, and archiving. Seismic refraction transects of $432 \mathrm{~m}(\times 2), 288 \mathrm{~m}$ $(\times 2)$, and $576 \mathrm{~m}(\times 1)$ were aligned perpendicularly to assumed position of tributaries valleys, in order to obtain information about the substrate topography. Field work was conducted with a Stratavisor NX (Geometrics) equipment, with a geophone frequency of $10 \mathrm{~Hz}$ spaced every $6 \mathrm{~m}$. Initial seismic signal was a hammer hit against a steel plate every $36 \mathrm{~m}$. Data processing, filtering, and two-dimensional (2D) profiling was performed by Pickwin, IXSeg2Segy and SeisImager/2D software's. Compact sand and clayey sand layers were identified by propagation speeds greater than $1750 \mathrm{~m} / \mathrm{s}$. Location and elevation of field data were recorded with a Trimble ${ }^{\circledR}$ R6 GPS Receiver.

All available datasets were combined in $\operatorname{ArcGIS}^{\circledR} 10$, using PT-TM06/ETRS89 datum and corrected in terms of vertical elevation to mean sea level (MSL). Offshore rocky outcrops location, late 19th century maximum tidal range, and actual topobathymetric DTM of Ria Formosa were also combined. Antecedent pre-Holocene topography was then interpolated using a hydrologically corrected DTM, which minimized sinks or depressions (Sousa et al., 2014).

Three sediment surface transects were delineated with the purpose of better describe actual depositional environments. Sites were selected based on distance to open ocean and to main intertidal channels. Samples were collected at regular intervals in order to obtain a vertical and lateral grain size distribution and foraminifera assemblage. Location and elevation of transects were acquired with a Trimble ${ }^{\circledR}$ R6 GPS Receiver.

\section{Laboratory analytical procedures}

Two cores were selected for a multi-proxy detailed laboratory analysis, including grain size distribution and mean, organic matter $(\mathrm{OM})$ content, color variation, shell identification, and benthic foraminifera assemblages. Selected cores followed the two major present-day tributaries of study area: RF1, at the midsection of the Ludo/São Lourenço water stream (26.5 m total core depth); and $\mathrm{RF} 4$, positioned $1.5 \mathrm{~km}$ from present-day Rio Seco mouth. Also, 37 surface samples retrieved in the three surface transects were analyzed in terms of grain size, in order to establish a description of actual deposition environments, using the same sedimentological analysis method as for the selected cores. 
Table I. Details of AMS ${ }^{14} \mathrm{C}$ dating samples.

\begin{tabular}{llllccl}
\hline Laboratory code & Borehole sample & Depth MSL $(\mathrm{m})$ & Conv. ${ }^{14} \mathrm{C}$ age (years) & $\delta^{13} \mathrm{C} \% \mathrm{o}$ & $2 \sigma$ cal. BP (years) & Material \\
\hline$\beta-334767$ & RFIc & -21.47 & $8620 \pm 50$ & -19.2 & $8932 \pm 175$ & Organic sediment \\
$\beta-334766$ & RFIb & -14.11 & $7650 \pm 40$ & 0.8 & $7856 \pm 165$ & Shell fragments \\
$\beta-334765$ & RFla & -13.41 & $8500 \pm 40$ & -18.5 & $8786 \pm 35$ & Organic sediment \\
$\beta-334773$ & RF4b & -12.65 & $8140 \pm 50$ & -25.3 & $8338 \pm 125$ & Charred veg. remains \\
$\beta-334769$ & RF2b & -8.54 & $6870 \pm 40$ & -25 & $7130 \pm 85$ & Charred veg. remains \\
$\beta-334770$ & RF3 & -7.65 & $7010 \pm 40$ & -23.8 & $7293 \pm 80$ & Organic sediment \\
$\beta-334772$ & RF4a & -7.45 & $7040 \pm 40$ & 1.7 & $7321 \pm 145$ & Shell (Cerithium vulgatum) \\
$\beta-324619$ & RFM2I & -6.8 & $6380 \pm 40$ & -24.8 & $6553 \pm 85$ & Organic sediment \\
$\beta-324618$ & RFM20 & -6.35 & $7210 \pm 40$ & -18.9 & $7473 \pm 85$ & Organic sediment \\
$\beta-324621$ & RFM22b & -6.25 & $7410 \pm 50$ & -22.5 & $7634 \pm 100$ & Organic sediment \\
$\beta-334768$ & RF2a & -5.44 & $5700 \pm 40$ & -0.8 & $5813.5 \pm 180$ & Shell (Venerupis decussata) \\
$\beta-324620$ & RFM22a & -5.38 & $6600 \pm 40$ & 1 & $6815 \pm 65$ & Shell (Loripes lucinalis) \\
$\beta-324622$ & RFM23 & -4.75 & $6480 \pm 40$ & -18.8 & $6670.5 \pm 70$ & Organic sediment \\
$\beta-324625$ & RFM40 & -4.5 & $6350 \pm 40$ & -27 & $6523.5 \pm 75$ & Organic sediment \\
$\beta-324623$ & RFM29 & -3.75 & $5800 \pm 40$ & 0.8 & $5966 \pm 80$ & Shell (Gastrana fragilis) \\
$\beta-324617$ & RFMI & -3.5 & $6470 \pm 50$ & -17.5 & $6654.5 \pm 75$ & Organic sediment \\
$\beta-135896$ & SB3, Base & -3.22 & $4770 \pm 40$ & -16.7 & $5815 \pm 127$ & Organic sediment \\
$\beta-135894$ & SC4, Base & -2.355 & $5720 \pm 40$ & -16.8 & $4687 \pm 114$ & Organic sediment \\
$\beta-135899$ & Sd5.5 & -2.18 & $2970 \pm 40$ & -16.5 & $2445.5 \pm 151$ & Organic sediment \\
$\beta-135898$ & SD4 & 0.045 & $2580 \pm 40$ & -18.6 & $2489 \pm 156$ & Organic sediment \\
$\beta-135893$ & SC4,Top & 0.14 & $3010 \pm 40$ & -17.6 & $1933 \pm 125$ & Organic sediment \\
$\beta-135895$ & SB3,Top & 0.31 & $2400 \pm 40$ & -19.4 & $1716 \pm 124$ & Organic sediment \\
$\beta-135897$ & Sala & 0.725 & $1120 \pm 50$ & -23.2 & $446 \pm 106$ & Organic sediment \\
\hline
\end{tabular}

MSL: mean sea level.

Sedimentological analysis. Selected cores were divided longitudinally in two halves, one for sample collection, and the other for color analysis and facies macroscopic description (later archived). A total of 34 samples from RF1 core and 26 samples from RF4 were collected representatively for grain size analysis. Sediment fractions larger than $250 \mu \mathrm{m}$ were dry sieved, and the remaining fraction $250 \mu \mathrm{m}$ was analyzed in a Malvern Mastersizer laser diffraction instrument, adding demineralized water with Sodium hexametaphosphate (SHMP) at $1 \mathrm{~g} / \mathrm{L}$ concentration in order to avoid particle flocculation. Sediment pre-treatment of the $250-\mu \mathrm{m}$ fraction included removal of organic content with $30 \%$ hydrogen peroxide $\left(\mathrm{H}_{2} \mathrm{O}_{2}\right)$. Grain size data were aggregated as percentage of total volume $(\% \mathrm{~V})$ using Quartz mean density $\left(2.65 \mathrm{~g} / \mathrm{cm}^{3}\right)$, and processed with the software GRADISTAT v4.0 (Blott and Pye, 2001) in order to obtain mean grain size (MGS) of total sample. Statistical parameters were determined in geometric $(\mu \mathrm{m})$ values after (modified) Folk and Ward (1957). OM content was calculated by approximation using loss on ignition (Schumacher, 2002), yielding a percentage loss of dry mass after a 4-h combustion at $550^{\circ} \mathrm{C}$. Before combustion, dry mass was weighted after an initial $4 \mathrm{~g}$ of each sample was oven dried at $40^{\circ} \mathrm{C}$ for $24 \mathrm{~h}$. Sediment color was measured in triplicates in $5 \mathrm{~cm}$ intervals on wet sample (preserved core halves) with a Colortron ${ }^{\mathrm{TM}}$ spectrophotometer. Data processing was made with ColorShop ${ }^{\mathrm{TM}}$ software, selecting CIE Lab Color, adequate to palaeoenvironmental color data (Francus, 2004).

Foraminifera analysis. About $10 \mathrm{cc}$ of sediment samples was collected, sieved through 500 and $63 \mu \mathrm{m}$ sieves after decanting away organic debris. After sieving, samples with a high sand content were dried and sprinkled with carbon tetrachloride to float off the foraminifera. Samples with large total numbers of foraminifera were divided with a modified plankton splitter (Scott and Hermelin, 1993), dividing the sample into eight equal parts in order to reduce the total number of individuals to a statistically representative count of 300-400. In samples with few identifiable foraminifera, however, 100 individuals were considered to be sufficient (Fatela and Taborda, 2002). Processed samples were examined under a binocular microscope in a gridded, circular counting tray. From the abundance data, the following parameters were calculated: faunal density (Ni), Shannon diversity index (Hs), species dominance and agglutinated/calcareous ratio $(\mathrm{A} / \mathrm{C})$, as well as the Foraminifera Index of Marine Influence (FIMI) (Boski et al., 2008). A stratigraphically constrained cluster (Grimm, 1987), based on the Edwards e Cavalli-Storza's distance with square root transformation of the percentage data and using the incremental sum of squares (Grimm, 2001), was used to define stratigraphic zones.

${ }^{14} \mathrm{C}$ time-scale. Chronology of the deposition environment was achieved by standard AMS by Beta Analytic. A total of 16 samples from 10 different cores were selected and retrieved from the inner part of the cores, consisting mostly of thin $(1 \mathrm{~cm})$ slices of organic sediment, bivalve and gastropod shells assessed as in living position, and coal fragments (Table 1). The core depth at which samples were collected was mainly focused in retrieving a baseline age for the coastal system (first meter above ravinement surface) and at the middle section of the cores. Measured radiometric ages were then calibrated with CALIB v7.0 (Stuiver et al., 1993; Stuiver et al., 2014), applying a marine reservoir correction of $250 \pm 22$ years, available from the CALIB database. Calibrated dates are expressed in calibrated years Before Present (cal yr BP) as the midpoint of $2 \sigma$ confidence interval. Additional samples (7), retrieved from the work of Andrade et al. (2004), were included and calibrated accordingly in order to complement the depth/age model of Ria Formosa.

\section{Results}

\section{Present day sedimentary units}

In a barrier island delimited system, three major clastic depositional environments can be identified (Walker and James, 1992): (1) the subtidal to subaerial barrier-beach-dune complex; (2) the subtidalintertidal lagoon, tidal flats (TF), and marsh; and (3) the subtidalintertidal channels and tidal delta complexes. The scope of this work only focused in the latter two depositional environments, since they tend to be better preserved in the subsurface (e.g. Belknap and Kraft, 1985). As such, a description of present-day depositional 
Table 2. Depositional environments predominant in the inner section of the RFBIS.

\begin{tabular}{|c|c|c|}
\hline $\begin{array}{l}\text { Depositional } \\
\text { environment }\end{array}$ & Description & Sediment properties \\
\hline Salt marsh (SM) & $\begin{array}{l}\text { Characterized by low-energy hydrodynamic conditions and sub- } \\
\text { divided according to inundation periods related to tidal flooding: } \\
\text { (I) supratidal, higher than I.5 m above MSL (only flooded at } \\
\text { high astronomical tides); ( } 2 \text { ) higher intertidal, I.5-I m above } \\
\text { MSL; and ( } 3 \text { ) lower intertidal, I-0.5 m above MSL. Halophyte } \\
\text { vegetation is abundant, with higher diversity toward the upper } \\
\text { limits, reflecting a clear vertical zonation. }\end{array}$ & $\begin{array}{l}\text { Sediment is dominated by the fine fraction. Silt content is gen- } \\
\text { erally above } 50 \% \text {, and clay between } 10 \% \text { and } 20 \% \text {. Coarse sand } \\
(>250 \mu \mathrm{m}) \text { is lower than } 5 \% \text {. Depending on the marsh location } \\
\text { in the coastal lagoon, mud deposits thickness can change from } \\
\text { centimetric to metric, respectively, closer to Lagoon beaches } \\
\text { or in more sheltered areas. Bioclastic content is very low or } \\
\text { absent. Sediment color varies from gray to brown. }\end{array}$ \\
\hline Tidal flats (TF) & $\begin{array}{l}\text { Distinctive flat morphology, establishing the transition between } \\
\text { the salt marsh and the channels. Halophyte vegetation is totally } \\
\text { absent. Occasionally covered by algal mats. }\end{array}$ & $\begin{array}{l}\text { Sediments are mainly fine (silt and clay) with coarser fraction } \\
\text { closer to the tidal channels. Bioclastic content is highly variable } \\
\text { according to the sampled location. Sediment color is gray to } \\
\text { dark gray. }\end{array}$ \\
\hline Tidal channel (C) & $\begin{array}{l}\text { Subdivided in three hierarchically ordered types: (I) main } \\
\text { channels, deeper, wider, and always active in all tidal cycles; }(2) \\
\text { secondary, narrower and shallower, active in high tides; and } \\
\text { (3) tertiary, only active during spring high tides. Mostly non- } \\
\text { depositional environment, with a generally stable morphology. } \\
\text { Evolution closely related to the interaction between halophyte } \\
\text { vegetation and hydraulic efficiency, except in areas close to } \\
\text { inlets. }\end{array}$ & $\begin{array}{l}\text { Channels sediment textures are highly variable depending on } \\
\text { types which are sampled. Main channel fills are mainly com- } \\
\text { posed of sand, with interstitial fine content in varying propor- } \\
\text { tions. Secondary channels are very similar to the main channels, } \\
\text { with decreasing values of the coarse fraction farther from the } \\
\text { main channels. Tertiary channels present a highest fine's content. } \\
\text { Bioclasts are abundant, reaching } 50 \% \text { of the total sample weight. } \\
\text { Sorting is low to moderate low, and asymmetry is negative to } \\
\text { very negative (reflecting high flows). Sediment color is gray to } \\
\text { light gray. }\end{array}$ \\
\hline $\begin{array}{l}\text { Lagoon beaches } \\
\text { (LB) }\end{array}$ & $\begin{array}{l}\text { Depositional environment located in the back barrier, or more } \\
\text { intermittently in the main channels margins. Its origin is related } \\
\text { to overwash episodes (input of beach sand over the barrier } \\
\text { island system into the lagoon) or from remobilization of aban- } \\
\text { doned flood deltas due to higher energy tidal currents. }\end{array}$ & $\begin{array}{l}\text { Essentially composed of medium to coarse sand, with a fine } \\
\text { sand content between } 5 \% \text { and } 15 \% \text {, and silt and clay from } 10 \% \\
\text { to } 15 \% \text {. Good to moderate sorting. Bioclastic content is very } \\
\text { low. Sediment color is generally brownish gray to gray. }\end{array}$ \\
\hline Flood deltas (FD) & $\begin{array}{l}\text { Very dynamic environments, depending on the hydraulic ef- } \\
\text { ficiency of the inlet and related main tidal channels. }\end{array}$ & $\begin{array}{l}\text { Composed mainly of well-sorted sands, with a very low content } \\
\text { in fine material. Bioclasts are fragmented and usually below } 10 \% \text {. } \\
\text { Silt and clay content is generally low, although fine sediment } \\
\text { can reach } 30 \% \text { in less dynamic areas of the inlet, specifically in } \\
\text { abandoned tidal deltas. Sediment color is in light hues. }\end{array}$ \\
\hline
\end{tabular}

MSL: mean sea level; RFBIS: Ria Formosa Barrier Island System.

environments is presented in Table 2, merging obtained results with data from previous works (Andrade, 1990; Barnhardt et al., 2002; Bettencourt, 1994) and Figure 2. Five depositional environments which are individualized in the backbarrier sheltered environment were grouped in two major lithosomes. SM and TF are part of the silt dominated sediments group. In this group, sand content is generally very low $(<10 \%)$, reflecting low tidal energy and/or the presence of halophyte vegetation. Sediment color is generally dark as a result of higher OM content. The second group corresponds to the sand dominated sediments. Tidal channels (C), Lagoon Beaches (LB), and Flood Deltas (FD) are part of this group. Coarser sediment fraction is generally high $(>60 \%)$. Tidal channels show however a highly variable amount of fine fraction, mostly dependent on the proximity to main tidal channels, inlets, or barrier island. Sorting therefore oscillates from poorly to well sorted (in FD). From the collected surface samples, a predominance of silty sediments is observable (Figure 2). The proximity to channels or barrier island translates into larger grain sizes. Finer fraction is only dominant in the SM environment, sampled at Ramalhete transect.

\section{Holocene stratigraphy}

The complete stratigraphic sequence of the selected boreholes is presented in Figure 3. Samples dated through radiocarbon age are identified as well as textural characteristics and OM content. Macroscopic calcareous shells abundance and type are indicated by the respective icon next to the MGS column. The FIMI is based on the cluster analysis of the foraminifera assemblages within the sedimentary sequence (Figure 4), summarizing also faunal density $(\mathrm{Ni})$, Shannon diversity index $(\mathrm{Hs})$, species dominance $(\mathrm{J})$, and agglutinated/calcareous ratio $(\mathrm{A} / \mathrm{C})$ (Camacho et al., 2016).

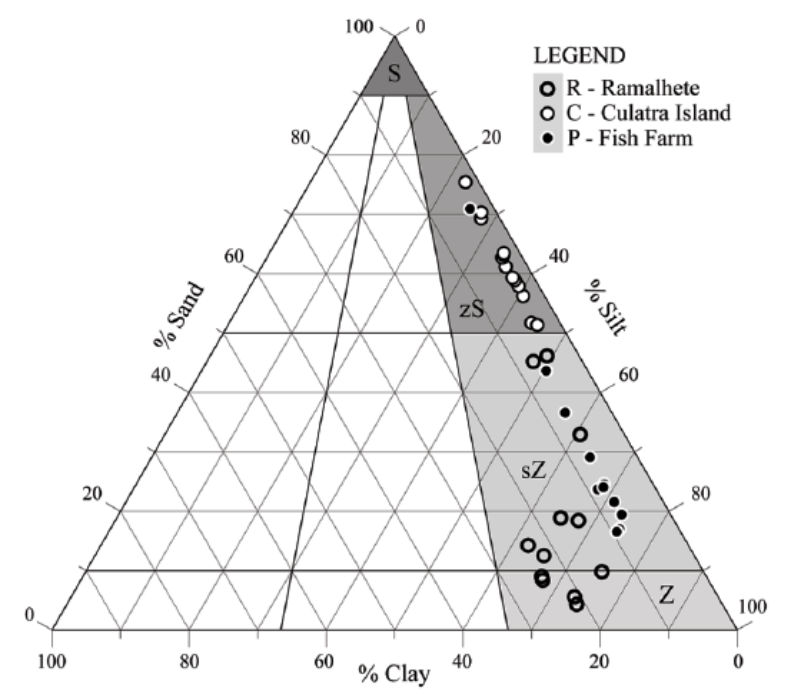

Figure 2. Granulometric characterization of surface sediment samples from three transects on Folk and Ward (1957) ternary diagram.

S: sand; zS: sandy silt; sZ: silty sand; Z: silt.

\section{Depositional environments interpretation of core RFI}

- P: Pleistocene basement ( -26.5 to $-24.0 \mathrm{~m})$ from the Last Glacial Maximum to $\sim 10,000$ cal. yr BP

The first $1.5 \mathrm{~m}$ (from -26.5 to $-25 \mathrm{~m}$ ) consists of a very poorly sorted compact clay and sand, brown to red color due to ferruginous pigments, and abundant pebbles ranging from 5 to $15 \mathrm{~mm}$. A sandier layer with small pebbles $(<5 \mathrm{~mm})$ follows until the $-24.6 \mathrm{~m}$ with 


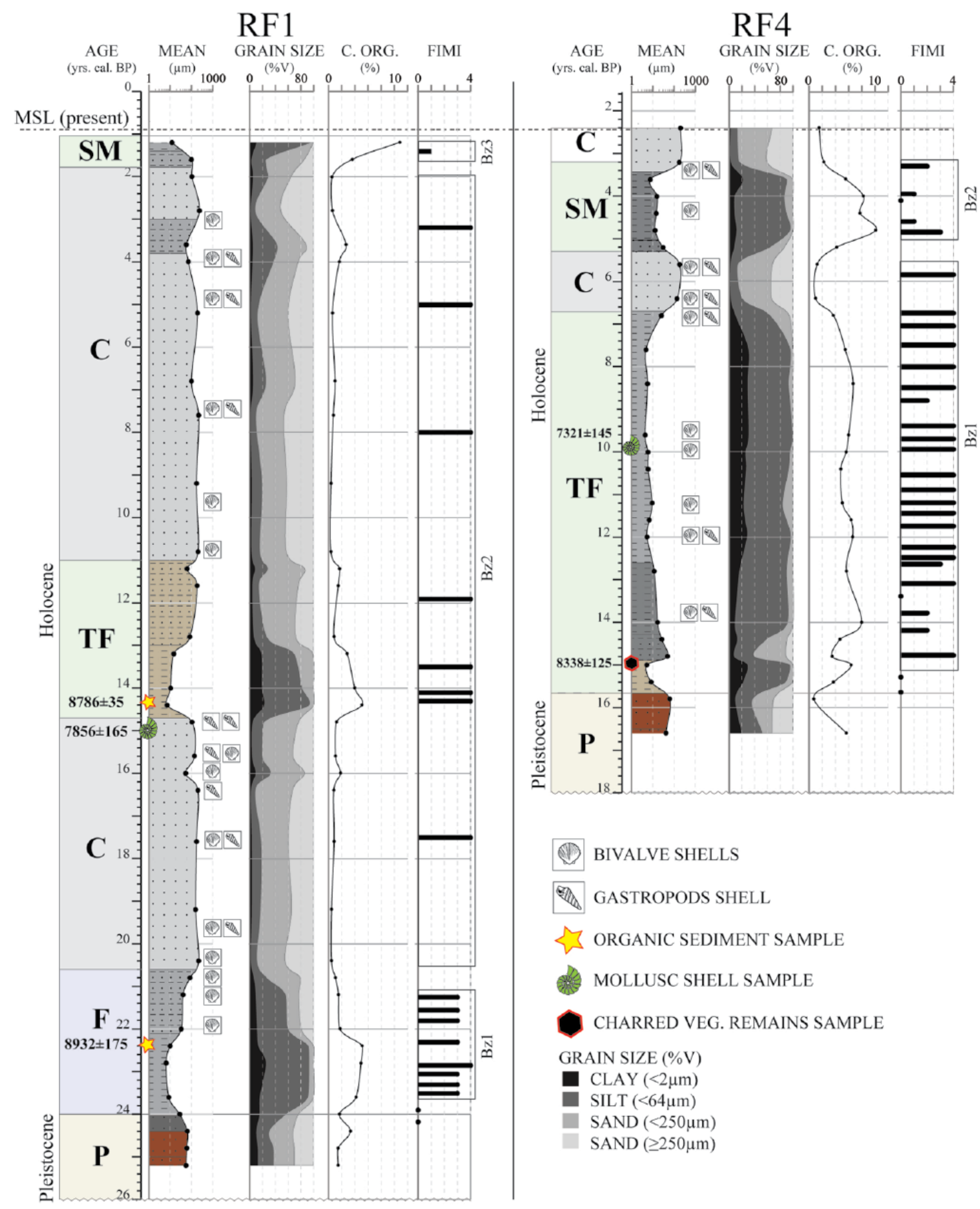

Figure 3. Lithology and the inferred depositional environments in the cores RFI and RF4. See Table 2 for description of Units: C (tidal channel), TF (tidal flat), and SM (salt marsh). Units P (Pleistocene basement) and F (fluvial to open estuary) are described in the interpretation of core RFI.

occasional dark spots due to the presence of decomposed OM. This unit is topped by a very poorly sorted, dark gray sand, with dark reddish tones. MGS is very similar in these sections; averaging 59.61 $\mu \mathrm{m}$. Similar very poorly sorted sediments of reddish/yellow color cropping out in the surrounding region were ascribed to the Pleistocene Ludo Formation, deposited in alluvial to colluvial high-density flow environment (Moura, 1998; Moura and Boski, 1999).

- F: Fluvial open estuary ( -24.0 to $-20.6 \mathrm{~m})$ between $\mathrm{min}$. $\sim 10000$ cal. yr BP and $\sim 9000$ cal. yr BP

This unit is subdivided in two sections. The reddish Pleistocene sediments are followed until $-22.1 \mathrm{~m}$, by a gray colored clayey silt layer, with dark brown spots enriched in OM (average content of $4.76 \%)$. Thin sandy layers bearing occasional coarser grains $(<3 \mathrm{~mm})$ are discernible, although with grading and diffuse boundaries. Until the top of this unit follows a gray sandy silt section, increasing in MGS from 13.28 to $52.27 \mu \mathrm{m}$. OM content is reduced in this section to an average value of $1.46 \%$. Shell fragments $(<5 \mathrm{~mm})$ are commonly observable throughout this section. Foraminifera content points to a low intertidal environment (FIMI 3), with a co-dominance $>60 \%$ of Haynesina germanica and Ammonia tepida species. The first section of this unit shows a very small presence of Jadammina macrescens with an average relative abundance of $4.8 \%$. FIMI 4 (sample $-22.9 \mathrm{~m}$ ) is defined by decrease in relative abundance of Haynesina germanica and an increase of Ammonia tepida, as well as an increase in exotic species such as Asterigerinata mamilla, 

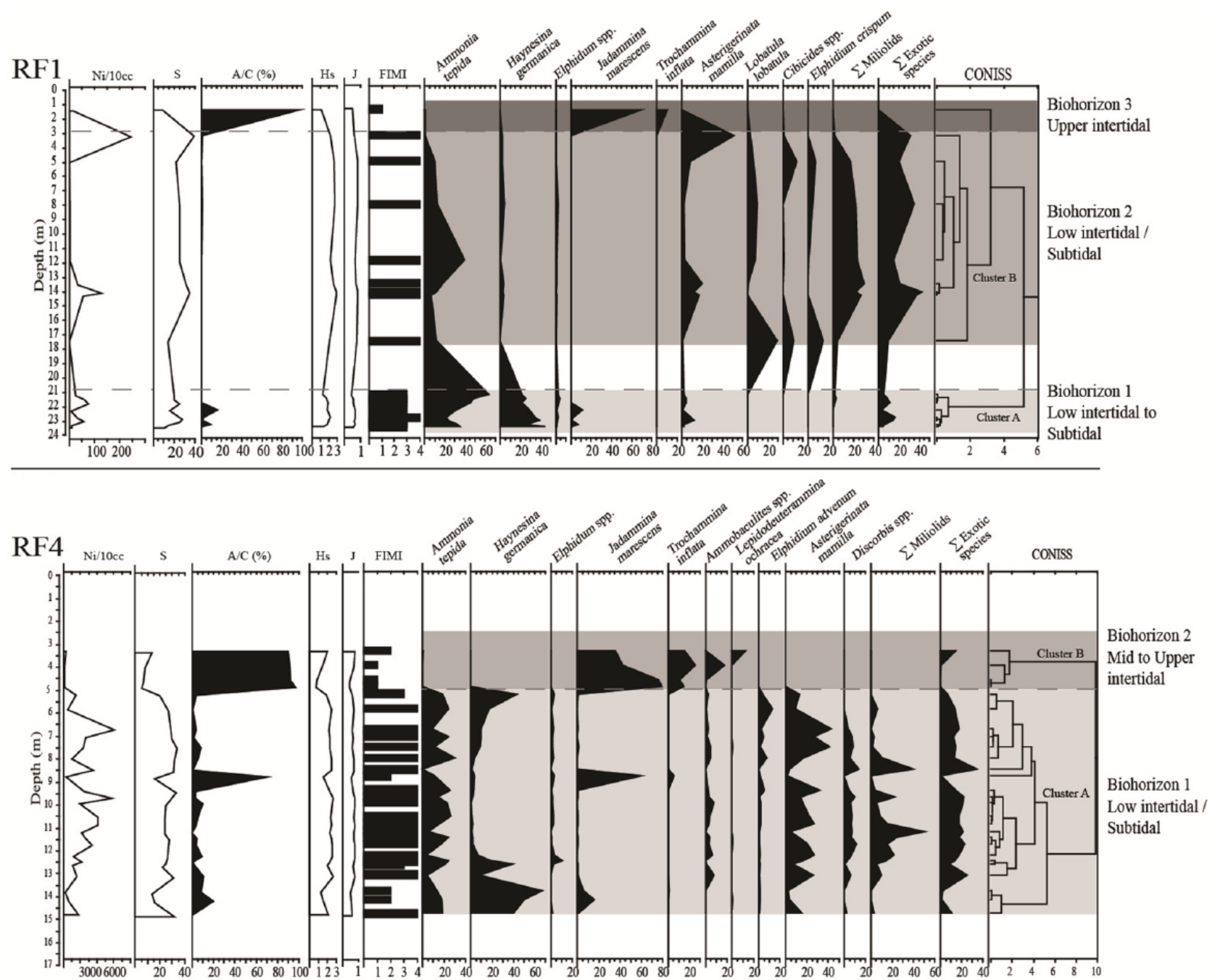

Figure 4. Cluster analysis of foraminifera assemblages in the boreholes RFI and RF4 and resulting biohorizon classification.

Lobatula lobatula, Elphidium crispum, Bolivina spp., Cibicides spp., and Discorbis spp.

- C: Tidal channel $(-20.6$ to $-14.7 \mathrm{~m})$ between min. $\sim 9000$ cal. yr BP and $\sim 8300$ cal. yr BP

This unit consists of a poorly sorted to very poorly sorted gray sand. Between -18 and $-15.6 \mathrm{~m}$, the sediment presents lighter hue. MGS ranges from $\sim 218$ and $\sim 158 \mu \mathrm{m}$ from the bottom of the unit until the $-16.4 \mathrm{~m}$. A siltier section is observable at $-16 \mathrm{~m}$, with a MGS of $\sim 53 \mu \mathrm{m}$, then changing to a fine sand with an average MGS of $\sim 122 \mu \mathrm{m}$. Shell fragments are abundant between -20.4 and $-19.6 \mathrm{~m}$ and -16.4 and $-17.6 \mathrm{~m}$, with numerous gastropod shells of Bittium sp. in the latter. A large cluster of Bittium sp. shells was observed at the top of this unit. OM content is always under $1 \%$, except at $-16 \mathrm{~m}$ where it reaches $1.84 \%$. A single sample $(-17.5 \mathrm{~m})$ was analyzed in terms of foraminifera content, pointing to a subtidal environment (FIMI 4), with a dominance of Lobatula lobatula, Cibicides spp., Elphidium crispum, and Elphidium sp. species.

- TF: Tidal flat ( -14.7 to $-11 \mathrm{~m})$ between min. $\sim 8300$ cal. yr $\mathrm{BP}$ and $\sim 7800$ cal. yr BP

Sharp change in textural composition and color with respect to the previous unit is observed. The bottom half of this unit (from $-14.7 \mathrm{~m}$ to $-13 \mathrm{~m}$ ) consists of a very poorly sorted brown gray clayey silt, with MGS increasing toward the top of this section from 7.2 to $14.73 \mu \mathrm{m}$. OM content decreases toward the top from $5.09 \%$ to $2.83 \%$. The top half $(-13$ to -11 $\mathrm{m}$ ) is composed of a poorly sorted to very poorly sorted laminated sand and silty sand. MGS ranges between 53.55 and $183.34 \mu \mathrm{m}$. OM content in this section is generally low with an average value of $1.35 \%$. Shell fragments (mainly gastropods) are rarely present, although more abundant in the transition between the bottom section and the top section. At $-11.2 \mathrm{~m}$, a significant amount of vegetal debris is observed. Foraminifera assemblage shows an increased proportion of Miliolids and exotic species, and a smaller relative abundance of Ammonia tepida and Asterigerinata mamilla species, thus pointing to FIMI 4, a subtidal environment.

- C: Tidal channel ( -11 to $-1.8 \mathrm{~m})$ between $\min . \sim 7800 \mathrm{cal}$. yr BP and $\sim 3200$ cal. yr BP

It consists of a rather monotonous sequence of gray to light gray poorly sorted sand. from -3.8 to $-3 \mathrm{~m}$, a section of laminated sand is observed, with higher silt content. Average MGS is $~ 176$ $\mu \mathrm{m}$, except in the laminated section where it is $\sim 64 \mu \mathrm{m}$. In terms of OM content, average value in the sandy section is $0.63 \%$, while in the silty portion is $2.18 \%$. Shell fragments are frequent throughout the whole unit, with occasional fully preserved shells of both gastropods and bivalves. Well-preserved vegetable fragments are observed between -5.6 and $-3.6 \mathrm{~m}$. Foraminifera assemblage points to the continuity of a subtidal environment (FIMI 4), with a large relative abundance of 
Miliolids and exotic species, and a peak of the Asterigerinata mamilla species observable at $-5 \mathrm{~m}(51.6 \%)$.

- SM: Salt marsh ( -1.8 to $-0.7 \mathrm{~m})$ between min. $~ 3200$ cal. yr BP and $\sim 2100$ cal. yr BP

This unit consists of a poorly sorted gray sandy silt and clayey silt. MGS decreases from 100.58 to $12.21 \mu \mathrm{m}$ toward the top of the unit, with parallel increase of OM content from $3.64 \%$ to $10.83 \%$. Foraminifera content is mainly co-dominated by the Jadammina macrescens and Trochammina inflata species (81\%), pointing to FIMI 1, related to a upper intertidal environment. This unit is topped by an anthropic soil resulting from the construction of salt ponds.

\section{Depositional environments interpretation of core RF4}

- P: Pleistocene basement ( -17 to $-15.7 \mathrm{~m})$ from the Last Glacial Maximum to $\sim 10000$ cal. yr BP

This unit is similar to the base section of RF1 borehole. Bottom sequence (first $0.3 \mathrm{~m}$ ) composed of very poorly sorted reddish compact clay with small pebbles, passing into OM enriched (5.65\%) transition spotted layer into the overlaying Holocene sequence. A red/yellow very poorly sorted fine sand with disseminated fine gravels follows.

- TF: Tidal flat $(-15.7$ to $-6.7 \mathrm{~m})$ between min. $\sim 8600$ cal. yr BP and $\sim 7300$ cal. yr BP

This unit begins with a $1.4 \mathrm{~m}$ sequence of brown gray/gray clayey silt to sandy silt section. Brownish hue is characteristic to horizons enriched in OM varying from $\sim 3.7 \%$ to $\sim 6.4 \%$. Shell fragments are very abundant in the sandier layers. Despite the absence of foraminifera, most probably due to dissolution, in the first meter of the unit, the sample at $14.8 \mathrm{~m}$ is very rich in Haynesina germanica, Ammonia tepida, and Asterigerinata mamilla and some Miliolids, pointing to FIMI 4 low intertidal. The following sequence from -14.3 to $-6.7 \mathrm{~m}$ constitutes the longest texturally continuous section of the borehole, consisting of a dark gray to gray clayey silt. Clay content amounts to more than $20 \%$ of sediment volume, except in the slightly coarser first $1.5 \mathrm{~m}$. MGS is below $12 \mu \mathrm{m}$, with an average of $9.29 \mu \mathrm{m}$. Only the first and last samples of the unit are coarser, with MGS of 16.8 and $25.37 \mu \mathrm{m}$, respectively. OM content is generally high, oscillating between a minimum of $3.7 \%$ and a maximum of $7.95 \%$, with an average value of $5.82 \%$. Shell fragments of both bivalve and gastropods are very abundant, especially in the top half of the section. Bivalve shells in living position are observed in several parts of the profile. Foraminifera assemblages can be subdivided in two distinct biohorizons. The first meter of the unit is characterized by a clear dominance of Haynesina germanica and Ammonia tepida species, with a significant relative abundance of Jadammina macrescens and a change in the agglutinated/calcareous shell ratio, pointing to a shallow intertidal environment and FIMI 2. The remainder of the unit's foraminifera content is marked by the abundance of Miliolids, Ammonia tepida, and Asterigerinata mamilla species, indicating the prevalence of low intertidal environment and FIMI 4. Jadammina macrescens is prevalent throughout this section though with a relative abundance lower than $1.5 \%$, except in the $-8.8 \mathrm{~m}$ sample, where it amounts to $59.6 \%$ indicating FIMI 2 value.

- C: Tidal channel $(-6.7$ to $-5.3 \mathrm{~m})$ between min. $7300 \mathrm{cal}$. yr BP and $\sim 6400$ cal. yr BP

A passage to the light gray sandy layer, with MGS average value of $161.27 \mu \mathrm{m}$ marks an abrupt change in depositional dynamics with respect to the previous unit. Shell fragments of both bivalve and gastropod species are particularly abundant especially in the coarser horizons and $\mathrm{OM}$ content decreases sharply to values close to $1 \%$. However, the abundance of Ammonia tepida, Haynesina germanica, and Asterigerinata mamilla indicates the continuation of FIMI 4, subtidal environment although in less sheltered hydrodynamic conditions.

- SM: Salt marsh 5 ( -5.3 to $-3.4 \mathrm{~m})$ between min. $\sim 6400$ cal. yr BP and $\sim 4700$ cal. yr BP

Sediment texture shifts to dark gray sequence of clayey silt, with a MGS of $\sim 12 \mu \mathrm{m}$ on average, except in the first $0.2 \mathrm{~m}$ where it reaches typical silt values of $30.7 \mu \mathrm{m}$. Laminations of organic material are observable in the bottom half, followed by very abundant dark brown mottles enriched in OM in the top half meter. OM content is generally high, between $10.1 \%$ and $5.54 \%$ (an average of 7.9\%). Shell content is low, where small fragments occur in the coarser bottom layer, although occasionally millimetric well-preserved gastropods are observed. Foraminifera assemblage changes drastically, pointing to higher intertidal conditions and the co-dominance of Jadammina macrescens and Trochammina inflata species, with Ammobaculites sp. as accessory taxa points to FIMI 1.

- C: Tidal channel ( -3.4 to $-2.3 \mathrm{~m}$ ) between $\min . \sim 4700 \mathrm{cal}$. yr BP and $\sim 3700$ cal. yr BP

It consists of a light gray poorly sorted sand with an average MGS of $188.96 \mu \mathrm{m}$. Contact with underlying unit is marked by abundant shell fragments. Foraminifera content points to lower intertidal conditions with associated FIMI 2, also marked by a co-dominance of Jadammina macrescens and Trochammina inflata species. Relative abundance of exotic species reaching $14.3 \%$ indicates free exchange with marine environment. This unit is overlain by a $2.3 \mathrm{~m}$ landfill brought to the construction of the Faro harbor.

\section{${ }^{14} \mathrm{C}$ chronology of age/depth relation}

In total, 16 samples from multiple origins were used to determine ${ }^{14} \mathrm{C}$ age, all by AMS method. Seven dated samples were added from previous results (Andrade et al., 2004) in order to achieve a more complete coverage of depth/age relation in the RFBIS sediment profiles (Figure 5). Most of the dated material was OM disseminated in the sediment (16) and the remainders were intact bivalve shells in living position (4), charred vegetal remains (2), and shell fragments (1). Boski et al. (2008) and Delgado et al. (2012) who proposed SL curves for SW Iberia embracing last 13 kyr focused in the sedimentary infill of Guadiana Estuary. Here, we expand the regional SL reconstruction during the Holocene within the confidence interval of the linear age/depth relation in the infill of Ria Formosa.

Two separate phases of infilling are discerned. The first phase, from ca. 10000 cal. yr BP to 7250 cal. yr BP, corresponds to a period of rapid SLR, with an average rate of $7 \mathrm{~mm} / \mathrm{yr}$. In the following phase, from $7250 \mathrm{cal}$. yr BP to present, SLR decelerated substantially to a rate of ca $1 \mathrm{~mm} / \mathrm{yr}$. Both segments are characterized by highly significant correlation coefficients $-R^{2}$ (Figure 5). Three main sources of vertical uncertainty in establishing a direct correspondence between past SL and the present reference datum from the position and dated samples were considered (see Delgado, 2012). The first corresponds to the error in establishing the depth within the borehole and is estimated in \pm 0.2 m given $90 \%$ of core recovery. The second, $\pm 1.4 \mathrm{~m}$, regarding the spring mean tidal range amplitude for dated samples collected in mudflat/SM environments. Finally, $+3 \mathrm{~m}$ for samples recovered from tidal channel environments, equal to average depth of primary channels in Ria Formosa. 


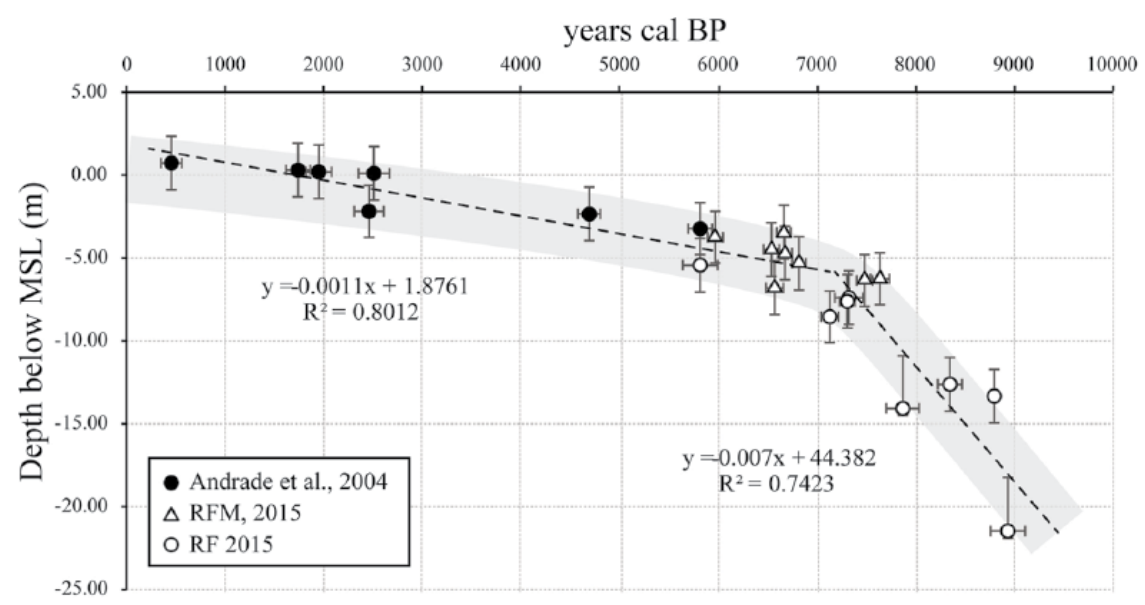

Figure 5. Depth/age plot of the dated samples from RFBIS. The linear regression equations were calculated assuming a data split at the 7250 cal. yr BP, highlighting an upper and lower segments. The gray area represents a 4-m envelope visual aid.

\section{Discussion}

The interpretation of gathered lithological and foraminifera information within the ${ }^{14} \mathrm{C}$ geochronological framework allowed to infer main stages in the geomorphological evolution of RFBIS during the Holocene. Considering that only two cores were interpreted with finer detail, our results provided a general depositional environment change description. The following discussion outlines a conceptual model of the system evolution imposed during two phases of SLR observed during the Holocene: an early- to mid-Holocene fast rate, followed by the mid-Holocene slowdown. The influence of the antecedent, pre-inundation surface morphology (Sousa et al., 2014) on the evolution of the system is presented according to two separate sub-basins during the first phase (fast SLR rate), later evolving as a single system.

\section{Ludo sub-basin}

The Ludo sub-basin consists of terminal section of a tributary valley, which drains the present-day Ludo/S. Lourenço watershed (ca. $60 \mathrm{~km}^{2}$ ) (Figure 6, Ludo/ São Lourenço). It is a fluvial palaeovalley that was incised into the Pleistocene, composed of dark red poorly sorted, alluvial to colluvial high-density flow sediments of Ludo Formation. This erosional surface, created on delta fan deposits, is generally to attribute the Last Glacial Maximum (LGM) lowstand (Moura and Boski, 1999). The earliest Holocene sediments recovered from borehole RF1 point to the transition from fluvial to open estuary environment. This transgressive unit was deposited between 10,000 cal. yr BP and 9000 cal. yr BP when MSL was 25 to $18 \mathrm{~m}$ below the present level, respectively (e.g. Delgado et al., 2012). The poorly sorted silt sediments are interpreted as belonging to the facies of a distal tidal reach of a river estuary, corresponding to a shallow low intertidal environment. Marine transgression is reflected by the increase in exotic, shelf, foraminifera species, and as a whole the unit might represent a transgressive shoreface draped by Holocene mud that extended from the palaeoestuary (Riggs et al., 1995). Sediment dynamics changed as SL was flooding the palaeovalley at accelerated pace. Between 9000 cal. yr BP and 8500 cal. yr BP, the higher energy landward moving sandy sediments became a part of the palaeovalley infill. The estuary expanded further inland, in parallel to the development of a regressive shoreface which formed along barrier island stretches according to the local availability of sediment (Riggs et al., 1995). In the following period, from 8500 cal. yr BP to 7500 cal. yr BP, the Ludo sub-basin became sheltered behind the first barrier islands, which formed in response to increased sediment availability and reduction of back barrier accommodation space. The existence of a narrow area behind the newly formed barrier islands induced the growth of $\mathrm{SMs}$, which in its place, decreased the barriers landward migration (Walters et al., 2014). The longshore drift sediment transport became the dominant source of mostly sandy material at the subbasin entrance with related tidal inlet migration. Inside the subbasin, a TF developed behind a closed or abandoned tidal inlet, composed mostly of muddy sediments without mollusk shells. With the SLR slowing down around $7500 \mathrm{cal}$. yr BP to $1.1 \mathrm{~mm} / \mathrm{yr}$, barrier islands consolidated their position, where tidal inlets remained an active feature at the palaeovalley extension. The tidal inlet lateral migration gave place to different depositional environments inside the sheltered area, changing from sandy deposits when close to inlet opening (tidal flood delta), to a dominant finer fraction related to intertidal sandy to muddy flats when the inlet opening moved further from the palaeovalley.

\section{Ria Formosa central sub-basin}

The Ria Formosa central sub-basin corresponds to the terminal section of the Biogal/ Marchil $\left(52 \mathrm{~km}^{2}\right)$ and Rio Seco $\left(70 \mathrm{~km}^{2}\right)$ watersheds (Figure 6; Biogal/ Marchil and Rio Seco). It is a wider and shallower area than the Ludo palaeovalley, separated from the latter by a gently sloping Pleistocene erosive surface. The central sub-basin has a generally shallower topography, with a large palaeosurface area, $10 \mathrm{~m}$ below present MSL (Figure 6; $8000 \mathrm{cal}$. yr $\mathrm{BP})$, with only a more pronounced palaeovalley close to the position of present-day Faro-Olhão main channel (Figure 1) (Sousa et al., 2014). Sediments reach depths of ca. $29 \mathrm{~m}$ in the outer boreholes and were interpreted as continuous sandy facies of flood tidal deltas (Bettencourt, 1994). Considering the depth/age model (Figure 5), these geomorphological features developed in the early Holocene (before or close to 10,000 cal. yr BP) when MSL was $25 \mathrm{~m}$ below present-day position. The steeper slope of the SE Ria Formosa shoreface limited the cross-shore translation of the sandy shoals, restricted to a smaller section of the central sub-basin. Despite the observed rapid SLR during the early Holocene, inland sand barrier movement was relatively slow. The lack of accommodation space in the backbarrier environment acted as limiting factor (Masetti et al., 2008). With high availability of sand supply, vertical growth of the islands is favored, remaining subaerial for a large period of time (Brenner et al., 2015). As SLR continued at a fast pace, flooding further inland, deposition in the inner sections of the sub-basin recorded less energetic conditions. Approximately 8500 cal. yr BP, SL was $-15 \mathrm{~m}$ below present position, creating the conditions for shallow depositional environments in the indented palaeovalleys. TFs and marshes developed in the shoreline margins in a first phase, later migrating landward 


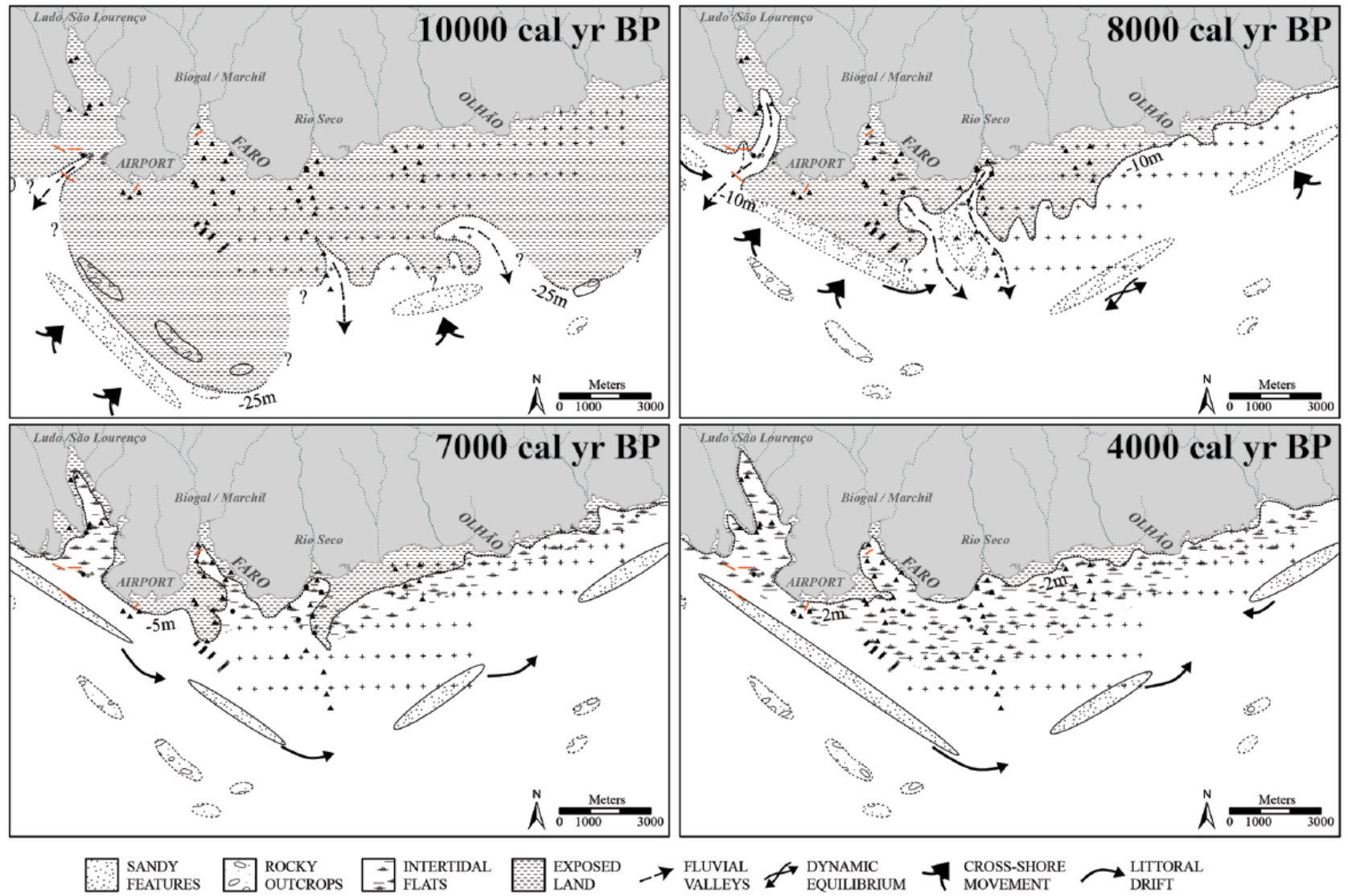

Figure 6. Palaeo-reconstruction of the changing geomorphology of the RFBIS during the Holocene. Four time steps were selected as representative: 10,000 cal.yr BP; 8000 cal.yr BP; 7000 cal.yr BP; and 4000 cal.yr BP.

in parallel to the on-going transgression. Considering the pretransgression surface, this area might have been enclosed behind an incipient barrier island that developed further offshore. Reaching the SLR slowdown close to 7500 cal. yr BP, fine sediments were the dominant facies in subtidal to low intertidal environments. The last phase of the rapid SLR gave place to a coastal lagoon, which could accommodate sediments at a fast rate in a low-energy environment. The sheltered environment experienced an alternation of facies related to the mid-Holocene SLR slowdown. As barrier islands attained their present position, inside the coastal lagoon sedimentation changed accordingly with inlet openings and related tidal channel migration.

\section{Holocene reconstruction of Ria Formosa}

A conceptual model for the origin and Holocene evolution of the RFBIS is presented in Figure 6. In this model, four time steps are selected as representative of the major changes that has occurred in the system. The inherited pre-transgression topography constituted the initial limiting factor for the development of ensuing geomorphologic features. As SLR quickly flooded in the early Holocene previously exposed surfaces at a rate of $7 \mathrm{~mm} / \mathrm{yr}$, large sandy shoals migrated landward following the gentle sloped platform (Masetti et al., 2008; Pilkey et al., 1989). The NW-SE-oriented rocky outcrops, described as detritic headlands resulting from beach-dune sediment cementation (Teixeira, 1998), suggest the existence of a perching area for the sandy shoals during the transgressive phase, as described by Thieler et al. (2014). With a high SLR rate, the shoreline is dominated by landward translation, while low SLR rates inhibit the cross-shore processes favoring alongshore transport (McBride et al., 1995). However, the Ria Formosa barrier islands are estimated to have developed $8000 \mathrm{cal}$. yr BP, when SLR rate was still very high $(7 \mathrm{~mm} / \mathrm{yr})$. The lack of backbarrier accommodation space, resulting from a steeper interfluve platform induced the vertical growth of the sandy shoals. Meanwhile, the palaeovalleys were quickly infilled by the available sandy sediment, in a process similar to semi-closed estuaries (Gregoire et al., 2017). Approaching the 7500 cal. yr BP SLR slowdown, the dynamic equilibrium of the newly formed detached barrier islands gave place to shore-parallel sediment transport, with spit growth over previously semi-opened estuaries. At this moment, MSL approaches $5 \mathrm{~m}$ below present-day position. The formation of a coastal lagoon and related low energy depositional environments behind a barrier island chain appears to be generalized in the Ria Formosa after 7000 cal. yr BP. As SLR rate reached a minimum of $1.1 \mathrm{~mm} / \mathrm{yr}$, wave and tidal energy transport processes became dominant. Depositional environments inside the coastal lagoon would change accordingly with tidal inlet migration, as a more mature state of the barrier islands gave place to an alternation between tidal channels and TFs development. Andrade et al. (2004) found that the backbarrier Marsh Detached Beaches were related to migration of mid- to late-Holocene tidal deltas (5700 to 4800 cal. yr BP). These results suggest the formal stabilization of the coastal lagoon system in the middle Holocene, confirming a gradual transition from subtidal sedimentation to intertidal mudflat, close to marshland. A generalized process of silting-up, essentially involving suspended load of terrestrial provenance and redistributed by tidal currents in a marine yet sheltered and confined environment, becomes dominant. The Late-Holocene Ria Formosa development under a SLR rate of 1.1 $\mathrm{mm} / \mathrm{yr}$ was dictated by the complicated interaction of wave and tidal influence, modifying the general geomorphological structure of the barrier island chain (width, length, number of inlets), a process that is still in operation (Ferreira et al., 2016).

The studied coastal system shows a quasi-continuous record of sedimentation that initiates in the early Holocene ca. 10,000 
cal. yr BP, when MSL along the SW Iberian Atlantic coast was approximately $25 \mathrm{~m}$ below the present level. During this time, the dominant depositional environment was envisioned as small dimension open estuaries, where fluvial streams drained further in the continental shelf. Most of the fluvial sediment input was trapped in the bayhead deltas and the axial zones of the estuaries (e.g. Trog et al., 2013). The early-Holocene marine transgression invaded the area at the rate of $7 \mathrm{~mm} / \mathrm{yr}$ of vertical rise. Large amounts of sand were brought into estuarine palaeovalleys. The whole barrier system recorded significant differences in terms of depositional environments during this phase, reflecting the Pleistocene erosive surface irregularities, with a deeper river thalweg at west and a shallower sub-basin at the system center. At ca. 8000 cal. yr BP, the maximum landward migration of the sandy shoals is observed, an event that preceded the mid-Holocene SLR rate slowdown, considered in previous works as the systems origin moment (e.g. Dias et al., 2000). SLR rate most probably did not change from 7 to $1 \mathrm{~mm} / \mathrm{yr}$ in abruptly. As Fruergaard et al. (2015) shows, in the Northern Wadden Sea, SLR rate changed from 8.8 to $4.4 \mathrm{~mm} / \mathrm{yr}$, and to $1.8 \mathrm{~mm} / \mathrm{yr}$ in nearly 2500 years since ca. 8000 cal. yr BP, progressively decreasing to $1.1 \mathrm{~mm} / \mathrm{yr}$ after the middle Holocene. Inversely, the last melt water pulse from the lake Agassiz drainage (Li et al., 2012) could have induced a MSL jump at an even faster rate, with clear implications in the system development at the final stage of the early Holocene. After 7250 cal. yr BP, the evolution of the backbarrier infilling is closely related to the decrease of SLR rate from 7 to $1.1 \mathrm{~mm} / \mathrm{yr}$. At this point, the vertical development of barrier islands surpassed the rate of SLR, giving place to aggradation processes without landward transgression. The large quantities of quickly drowned Holocene shoreface deposits could explain the sediment availability in the shoreline, suggesting an inner-shelf sediment source for the vertical growth of the barrier islands (Schwab et al., 2013). Within the sheltered backbarrier environment, vertical siltation progressively expanded TFs and marsh areas. The reduction of the water surface area in the lagoon led to a decrease in wind generated wave sediment transport resulting in vertical accretion of SM incised by tidal channels (Hunt et al., 2015). After 4000 cal. yr BP, the RFBIS attained its early maturation, with fully developed islands extending NW-SE in the western flank, and growing NEE at the eastern flank in a somewhat regressive process. The late phase of the system maturation was reached ca. 2200 cal. yr BP, where a minimal fetch distance due to sediment retention inside the lagoon system further enhanced the siltation of the backbarrier environment (Adlam, 2014).

\section{Final remarks}

Subsurface stratigraphy acquired from boreholes in the backbarrier area of RFBIS, south Portugal, combined with a multi-proxy analysis and three-dimensional (3D) surface model of the preHolocene topography, allowed to create the first comprehensive sequence of processes leading to the Holocene sediment infilling of the lagoon. The Holocene evolution of the barrier island system followed a twofold pattern due to a significant shift in SLR rate, changing from transgressive to aggradation processes. First, during the early Holocene ca. 10,000-8000 cal. yr BP, sand migrated landward as SL quickly flooded an irregular topography, giving place to bayhead deltas where water depth created accommodation space. Second, following the 7500 cal. yr BP SLR slowdown, the surface occupied by the flooded valleys diminished rapidly due to increasing sedimentation at the interfluves steeper margins. The geomorphology of the system quickly modified, giving place to dynamic equilibrium processes that maintained the present configuration of the RFBIS. The 3D pre-Holocene surface model proved to be a relevant information for the conceptualization of a coastal system evolu- tion, spatially constraining the factors that control the backbarrier environment infill and related barrier island formation.

\section{Funding}

Field work and samples analysis was funded by SIHER project (PTDC/CTE-GIX112236/2009). The study was developed within the EU Erasmus Mundus Joint Doctorate in Marine and Coastal Management (MACOMA) fellowship grant, under University of Algarve and University of Cadiz coordination.

\section{ORCID iD}

Carlos Sousa https://orcid.org/0000-0003-4616-2278

\section{References}

Adlam K (2014) Coastal lagoons: Geologic evolution in two phases. Marine Geology 355: 291-296.

Andrade C (1990) O ambiente de barreira da Ria Formosa, Algarve-Portugal. PhD Thesis, Universidade de Lisboa (in Portuguese with English Abstract).

Andrade C, Freitas MC, Moreno J et al. (2004) Stratigraphical evidence of Late-Holocene barrier breaching and extreme storms in lagoonal sediments of Ria Formosa, Algarve, Portugal. Marine Geology 210(1-4): 339-362.

Arnaud-Fassetta G, Bertrand F, Costa S et al. (2006) The western lagoon marshes of the Ria Formosa (Southern Portugal): Sediment-vegetation dynamics, long-term to short-term changes and perspective. Continental Shelf Research 26(3): 363-384.

Barnhardt WA, Gonzalez R, Kelley JT et al. (2002) Geological evidence for the incorporation of flood tidal deltas at Tavira Island, southern Portugal. Journal of Coastal Research 36: 28-36.

Belknap DF and Kraft JC (1985) Influence of antecedent geology on stratigraphic preservation potential and evolution of Delaware's barrier systems. Marine Geology 63(1-4): 235-262.

Bettencourt P (1994) Les environments sedimentaires de la côte Sotavento (Algarve, Sud Portugal) et leur évolution Holocéne et actuelle. PhD Thesis. Université de Bordeaux I (in French - unpublished).

Blott SJ and Pye K (2001) GRADISTAT: A grain size distribution and statistics package for the analysis of unconsolidated sediments. Earth Surface Processes and Landforms 26(11): 1237-1248.

Boski T, Camacho S, Moura D et al. (2008) Chronology of the sedimentary processes during the postglacial sea level rise in two estuaries of the Algarve coast, Southern Portugal. Estuarine Coastal and Shelf Science 772: 230-244

Brenner O, Moore LJ and Murray AB (2015) The complex influences of back-barrier deposition, substrate slope and underlying stratigraphy in barrier island response to sea-level rise: Insights from the Virginia Barrier Islands, Mid-Atlantic Bight, U.S.A. Geomorphology 246: 334-350.

Camacho S, Boski T, Moura D et al. (2016) Paleoenvironmental evolution of the Guadiana Estuary, Portugal, during the Holocene: A modern foraminifera analog approach. The Holocene 27(2): 197-235.

Carter RWG and Woodroffe CD (eds.) (1994) Coastal Evolution: Late Quaternary Shoreline Morphodynamics. Cambridge; New York: Cambridge University Press.

Chester DK (2012) Pleistocene and Holocene geomorphological development in the Algarve, southern Portugal. Geomorphology 153-154: 17-28.

Costa M, Silva R and Vitorino J (2001) Contribuição para o estudo do clima de agitação marítima na costa portuguesa. In: Proceedings of: 2as Jornadas Portuguesas de Engenharia Costeira e Portuária, International Navigation Association PIANC, 17-19 October 2001. Sines, Portugal (in Portuguese).

Costas S, Ferreira Plomaritis ÓTA and Leorri E (2016) Coastal barrier stratigraphy for Holocene high-resolution sea-level reconstruction. Nature Scientific Reports 6: 38726. 
Dabrio CJ, Zazo C, Goy JL et al. (2000) Depositional history of estuarine infill during the last postglacial transgression (Gulf of Cadiz, Southern Spain). Marine Geology 162(2-4): 381-404.

Davis RA Jr (ed.) (1994) Geology of Holocene Barrier Island Systems. New York: Springer-Verlag.

Davis RA Jr and Hayes MO (1984) What is a wave-dominated coast? Marine Geology 60(1-4): 313-329.

Delgado J, Boski T, Nieto JM et al. (2012) Sea-level rise and anthropogenic activities recorded in the late Pleistocene/ Holocene sedimentary infill of the Guadiana Estuary (SW Iberia). Quaternary Science Reviews 330: 121-141.

Denny JF, Schwab WC, Baldwin WE et al. (2013) Holocene sediment distribution on the inner continental shelf of northeastern South Carolina: Implications for the regional sediment budget and long-term shoreline response. Continental Shelf Research 56: 56-70.

Dias JA, Boski T, Rodrigues A et al. (2000) Coast line evolution in Portugal since the Last Glacial Maximum until present - A synthesis. Marine Geology 170(1-2): 177-186.

Fairbanks RG (1989) A 17,000-year glacio-eustatic sea level record: Influence of glacial melting rates on the Younger Dryas event and deep-ocean circulation. Nature 342(6250): 637-642.

Fatela F and Taborda R (2002) Confidence limits of species proportions in microfossil assemblage. Marine Micropaleontology 45: 169-174.

Ferreira O, Matias A and Pacheco A (2016) The East Coast of Algarve: A Barrier Island Dominated Coast. Thalassas 32(2): $75-85$.

Filipe A, Carvalho M and Capitão R (2000) Extreme sea waves of Faro. In: Proceedings of 3rd Symposium on the Atlantic Iberian Continental Margin, 25-27 September, Faro, Portugal. CIACOMAR, Universidade do Algarve, pp. 105-106.

Fisher JJ (1968) Barrier island formation: Discussion. Geological Society of America Bulletin 79: 1421-1426.

Folk RL and Ward WC (1957) Brazos River bar [Texas]: A study in the significance of grain size parameters. Journal of Sedimentary Research 27(1): 3-26.

Francus P (ed.) (2004) Image Analysis, Sediments and Paleoenvironments, vol. 7. Dordrecht: Kluwer Academic Publishers.

Fruergaard M, Møller I, Johannessen PN et al. (2015) Stratigraphy, evolution, and controls of a Holocene transgressiveregressive barrier island under changing sea level: Danish North Sea Coast. Journal of Sedimentary Research 85(7): $820-844$.

Gao S and Collins MB (2014) Holocene sedimentary systems on continental shelves. Marine Geology 352: 268-294.

Gregoire G, Le Roy P, Ehrhold A et al. (2017) Control factors of Holocene sedimentary infilling in a semi-closed tidal estuarine-like system: The bay of Brest (France). Marine Geology 385: 84-100.

Grimm EC (1987) Coniss: A Fortran 77 Program for stratigraphically constrained cluster analysis by the method of incremental sum of squares. Computers \& Geosciences 13(1): 13-35.

Grimm EC (2001) TGView. Springfield, IL: Research and Collection Center, Illinois State Museum.

Hayes MO and Fitzgerald DM (2013) Origin, evolution, and classification of tidal inlets. Journal of Coastal Research 68: 14-33.

Hoyt JH (1967) Barrier island formation. Geological Society of America Bulletin 79: 1125-1136.

Hunt S, Bryan KB and Mullarney JC (2015) The influence of wind and waves on the existence of stable intertidal morphology in meso-tidal estuaries. Geomorphology 228: 158-174.

Lambeck K, Yokoyama Y and Purcell T (2002) Into and out of the Last Glacial Maximum: Sea-level change during Oxygen Isotope Stages 3 and 2. Quaternary Science Reviews 21(1-3): 343-360.
Lario J, Zazo C, Goy JL et al. (2002) Changes in sedimentation trends in SW Iberia Holocene estuaries (Spain). Quaternary International 93-94: 171-176.

Li YW, Törnqvist TE, Nevitt JM et al. (2012) Synchronizing a sea-level jump, final Lake Agassiz drainage, and abrupt cooling 8200 years ago. Earth and Planetary Science Letters 315-316: 41-50.

López-Dóriga Ú and Ferreira Ó (2017) Longshore and crossshore morphological variability of a Berm-Bar System under low to moderate wave energy. Journal of Coastal Research 33(5): 1161-1171.

Lorenzo-Trueba J and Ashton AD (2014) Rollover, drowning, and discontinuous retreat: Distinct modes of barrier response to sealevel rise arising from a simple morphodynamic model. Journal of Geophysical Research Earth Processes 119(4): 779-801.

Masetti R, Fagherazzi S and Montanari A (2008) Application of a barrier island translation model to the millennial-scale evolution of Sand Key, Florida. Continental Shelf Research 28: 1116-1126.

McBride RA, Byrnes MR and Holand MW (1995) Geomorphic response-type model for barrier coastlines: A regional perspective. Marine Geology 126: 143-159.

Moore LJ, List JH, Williams SJ et al. (2010) Complexities in barrier island response to sea level rise: Insights from numerical model experiments, North Carolina Outer Banks. Journal of Geophysical Research Earth Surface 115(F3): 1-27.

Moura D (1998) Litostratigrafia do Neogénico terminal e Plistocénico na Bacia Centro-Algarve, Evolução Paleoambiental. PhD Thesis, Universidade do Algarve (in Portuguese with English abstract).

Moura D and Boski T (1999) Unidades litostratigráficas do pliocénico e plistocénico no Algarve. Comunicações do Instituto Geológico e Mineiro 86: 85-106 (in Portuguese).

Moura D, Veiga-Pires C, Albardeiro L et al. (2007) Holocene sea level fluctuations and coastal evolution in the central Algarve (southern Portugal). Marine Geology 237(3-4): 127-142.

Oliver TSN, Tamura T, Hudson JP et al. (2017) Integrating millennial and interdecadal shoreline changes: Morpho-sedimentary investigation of two prograded barriers in southeastern Australia. Geomorphology 288: 129-147.

Pacheco A, Vila-Concejo A, Ferreira O et al. (2008) Assessment of tidal inlet evolution and stability using sediment budget computations and hydraulic parameter analysis. Marine Geology 247(1-2): 104-127.

Pilkey O, Neal W, Monteiro JH et al. (1989) Algarve barrier islands: A non-coastal plain system in Portugal. Journal of Coastal Research 5(2): 239-261.

Pirazzoli PA and Pluet J (1991) World Atlas of Holocene SeaLevel Changes, vol. 58. Amsterdam: Elsevier.

Riggs SR, Cleary WJ and Snyder SW (1995) Influence of inherited geologic framework on barrier shoreface morphology and dynamics. Marine Geology 126: 213-234.

Schumacher BA (2002) Methods for the Determination of Total Organic Carbon (TOC) in Soils and Sediments. Report, Ecological Risk Assessment Support Center, Washington, DC.

Schwab WC, Baldwin WE, Hapke CJ et al. (2013) Geologic evidence for onshore sediment transport from the inner continental shelf: Fire Island, New York. Journal of Coastal Research 29(3): 526-544.

Scott DB and Hermelin JOR (1993) A device for precision splitting of micropaleontological samples in liquid suspension. Journal of Paleontology 67(1): 151-154.

Smith DE, Harrison S, Firth CR et al. (2011) The early Holocene sea level rise. Quaternary Science Reviews 30(15-16): $1846-1860$.

Sousa C, Boski T, Gomes A et al. (2014) Holocene reconstruction of the lagoon system of Ria Formosa, based on a pre-Holocene 
paleosurface digital terrain model. Comunicações Geológicas 101(1): 635-639 (in Portuguese with English Abstract).

Stanley DJ (1995) A global sea-level curve for the late Quaternary: The impossible dream? Marine Geology 125(1-2): 1-6.

Stuiver M, Reimer PJ and Reimer RW (1993) Extended 14C database and revised CALIB radiocarbon calibration program. Radiocarbon 35: 215-230.

Stuiver M, Reimer PJ and Reimer RW (2014) CALIB 7.0. Internet Program and Documentation. Available at: http://calib. org/calib/

Stutz ML and Pilkey OH (2011) Open-ocean barrier islands: Global influence of climatic, oceanographic, and depositional settings. Journal of Coastal Research 27(2): 207-222.

Swift DJP (1975) Barrier island genesis: Evidence from the central Atlantic Shelf, eastern U.S.A. Sedimentary Geology 14: 1-43.

Teixeira SB (1998) Identificação e Caracterização de Arribas Holocénicas Submersas ao Largo do Algarve (Portugal). Comunicações Geológicas 84(1): C35-C38 (in Portuguese).

Thieler ER, Foster DS and Himmelstoss EA (2014) Geologic framework of the northern North Carolina, USA inner continental shelf and its influence on coastal evolution. Marine Geology 348: 113-130.
Trog C, Höfer D, Frenzel P et al. (2013) A multi-proxy reconstruction and comparison of Holocene palaeoenvironmental changes in the Alvor and Alcantarilha estuaries (southern Portugal). Revue de Micropaléontologie 56(4): 131-158.

Van Heteren S (2015) Barrier Systems. In: Masselink G and Gehrels R (eds) Coastal Environments and Global Change. Hoboken, NJ: John Wiley \& Sons, pp. 194-226.

Vis GJ, Kasse C and Vandenberghe J (2008) Late Pleistocene and Holocene palaeogeography of the Lower Tagus Valley (Portugal): Effects of relative sea level, valley morphology and sediment supply. Quaternary Science Reviews 27(17-18): 1682-1709.

Walker RG and James NP (eds) (1992) Facies Models Response to Sea Level Change. 2nd Edition. St. John's: Geological Association of Canada.

Walters D, Moore LJ, Vinent OD et al. (2014) Interactions between barrier islands and backbarrier marshes affect island system response to sea level rise: Insights from a coupled model. Journal of Geophysical Research Earth Surface 119(9): 2013-2031.

Woodroffe CJ (ed.) (2003) Coasts: Form, Process, and Evolution. Cambridge: Cambridge University Press. 